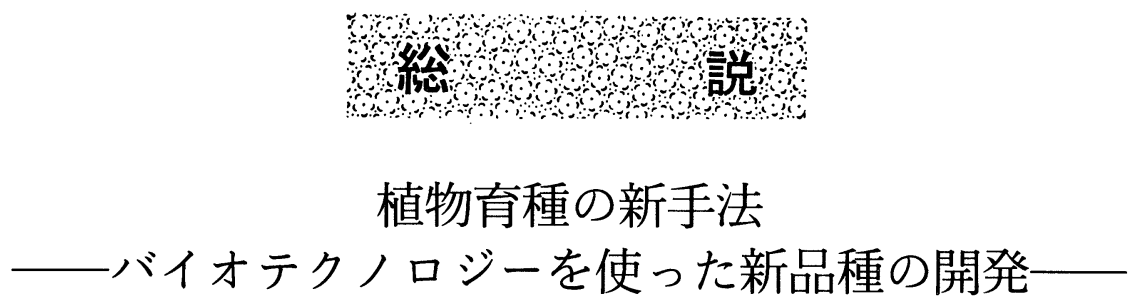

八 尋義 輝*

\title{
New Tools for Plant Breeding
}

\author{
Yoshiteru YAHIRO \\ (Plantech Research Institute: 1000, Kamoshida-cho, Midori-ku, \\ Yokohama-City, Kanagawa, Japan)
}

\section{1.はじめに}

私達は実に多様な食品を毎日口にしている. 最近は “食ブーム”で世界各国の料理や地方の特色のある食べ 物などが紹介され，一度は食べてみたいと言う気にさせ られる．食が満ち足りていることは，平和で安定した世 界情勢を反映したあのと言えるであろう。一部の局地的 な例外はあるものの，世界の食糧事情はここ 20 年ばか り極めて安定しており，むしろ生産過剩を背景とした問 題の方が大きくなって来ている感さえある.

食品は私達人類の生活を支える基盤であり, 関心が高 いのは当然かむしれないが，その関心の対象はそれぞれ 人により大きく違っている，ある人は飢餓問題を将来の 人口増加と結びつけて深刻にとらえようとするであろう し, また, 環境問題ともからめてその安全性に強い関心 を持つ人むいる．あるいは現在のグルメブームを多いに 楽しみたいと考えている人もいよう，食品は単に栄養 的，エネルギー的な充足だけでなく，嗜好性む強く，生 活の潤いにも繫がる性質のもので，その関心の持ち方は どうであれ，私達は常に食品や食糧と言った身近な問題 に強い関心を持って行きたと思う.

農業は食糧生産だけでなく，長期的にみれば人口問題 や環境問題との関係も含め, 多くの課題を抱えており, 多方面からの関心が寄せられている分野であある。ここ では世界の農業の実情とバイオテクノロジーを利用した 最新の品種改良の技術開発状況について概観してみたい と思う。

\section{2. 食糧生産の状況}

主要食糧である殼物の生産高は 1985 年の FAO 統計

* 植物工学研究所：横浜市緑区鴨志田町 1000
では世界全体で 18.4 億トンにのぼる. 作物別には表 1 に示したように, 麦類 7 億トン, 米とトゥモロコシがそ れぞれ 5 億卜ン弱で, この 3 作物で世界の人口を養って いると言っても過言ではない. この他にイモ類約 5 億卜 ン, 果物之野菜類が約 2 億トンづつ生産され, これらが 私達人類の主要な食糧となっている。

一方，世界の人口は 1988 年に 50 億人を突破し， 21 世紀初めには 60 億人に達すると予測されている. 図 1 にも示すように, 人口は確実に増え続けているが, 農地 はほとんど増加する余地はないと見られている. 従って 食糧増産のためには, 単位面積あたりの収量を増加させ るしか方法がないことになる。単純計算で行けば，現在 の収量レベルを $20 \%$ 増加させないと 60 億人の人口を 養うことができないことになる。しかし単位収量を上げ ることは生易しいことではなく，例えば我が国の稲作を 例として取り上げると, 明治時代の中期に育種が始まっ て以来一貫して $10 \mathrm{a}$ あたりの収量は増加しているが,

表 1．世界の主要穀物生産状況 (1985)

\begin{tabular}{|c|c|c|c|c|}
\hline 作 & 物 & 生産高 & $\begin{array}{c}\text { 作付面積 } \\
\text { (億 ha) }\end{array}$ & $\begin{array}{c}\text { 単位収量 } \\
\text { (t/ha) }\end{array}$ \\
\hline 小 & 麦 & 5.1 & 2.3 & 2.2 \\
\hline 大 & 麦 & 1.8 & 0.8 & 2.3 \\
\hline \multicolumn{2}{|c|}{ 米 } & 4.7 & 1.4 & 3.2 \\
\hline \multicolumn{2}{|c|}{ トウモロコシ } & 4.9 & 1.3 & 3.7 \\
\hline 豆 & 類 & 1.5 & - & - \\
\hline & 付 & 0.4 & - & - \\
\hline & & 18.4 & - & - \\
\hline
\end{tabular}

（FAO 生産年鑑より） 


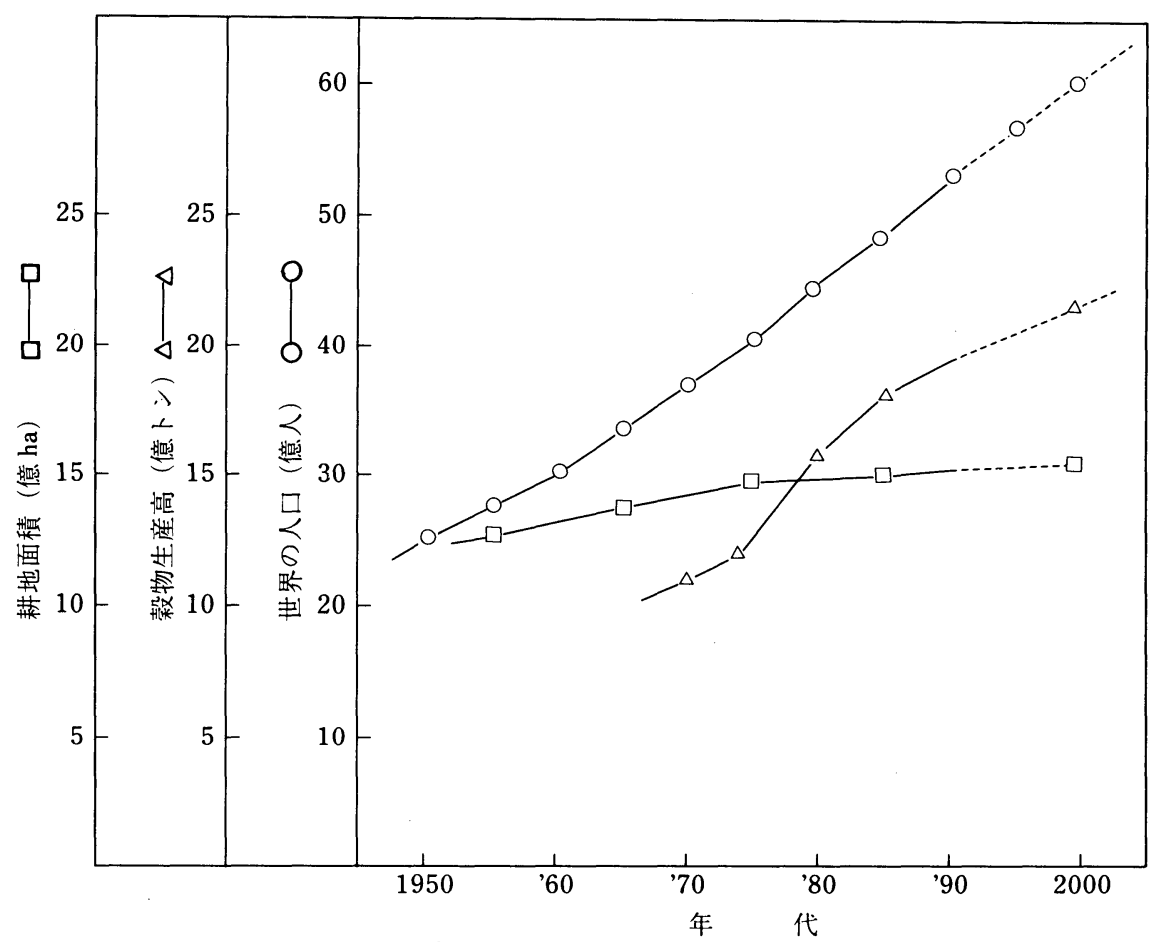

図 1。世界の人口と農業の動向

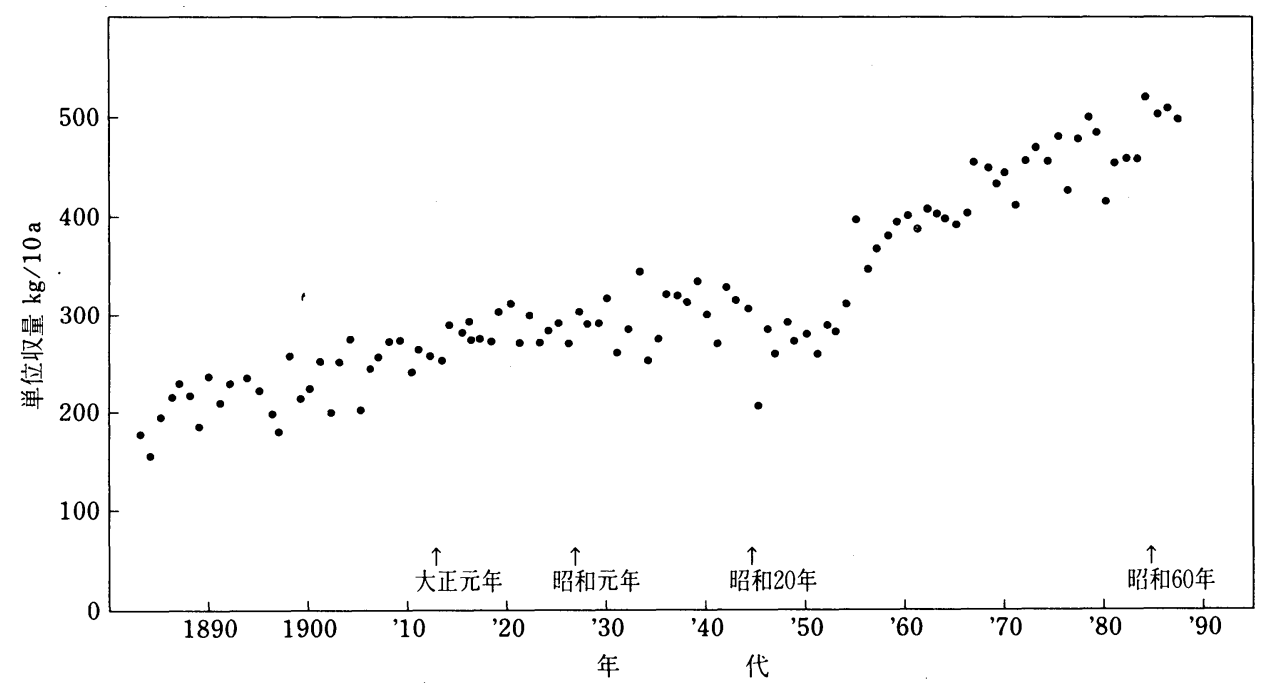

図 2. 我が国水稲の単位収量の推移

1900 年代当初. 200〜 $250 \mathrm{~kg}$ であったものが昭和の初 期に $300 \mathrm{~kg}$ 前後に達し, 現在は $500 \mathrm{~kg}$ を越える収量 となっている.（図 2）収量を 2 倍にするのに，実に 100 年近い歳月を要した訳である. 単位収量を上げるための 要因は, 灌溉, 排水などの栽培環境の整備, 肥料, 農薬 などの農業資材, 生産の源資となる優秀な種子など総合
的な農業技術のいずれもが重要な項目であり，これらの 技術を着実に高めて行くことが食糧の安定供給のための 確かな道程であると考えられる。

我が国の農業事情を見てみると，1986 年の総生産高 は約 13 兆円 (林業, 水産, 畜産を含む) で, これは GNP の $3.9 \%$ に相当する．その内訳は表 2 に示すとおりであ 
る.我が国の農業の特徴は自給率が他に例を見ない程低 いという点にある. 食糧全体の自給率は約 50\%, 穀物の 自給率は $30 \%$ という低い状況である。これは技術的な 問題だけでなく，経済的背景や農業政策的な面が強く簡 単に答えが見つかる問題ではないが, 食糧という生活の 基本物質にかかわる問題なので, 慎重に無理のない解答 を引き出すよう努力していくことが肝要だと思う.

ところで，世界の食糧の需給バランスを見てみると， 表 3 に示したように主要生産国数か国で全生産高の約 $70 \%$ 占めており，極めて偏った生産状況となってい る. 輸出入量は生産高の $12 \%$ にあたる約 2.2 億トンと なっており, 主要輸出国 5 か国で全輸出量の 86\%を占 めている. 最近, 各国の農業生産性は非常に向上してお り，特にアジア各国ではおおむね自給体制が整ってきて いる. 主要な輸入国はソ連, EC 域内, 日本と数か国にす ぎない状況となっている.

以上述べてきたように，世界全体では現時点では食糧 は過剩生産気味であるが, 局地的にみると, 気象条件や 病虫害の発生などの農業環境の悪化，人口増加に対する 食糧の増産, 品質の向上など将来に対する課題もたくさ ん抱えている. 農産物に対する要望は時代時代の二ーズ を反映して刻々と変化している. 品種に対する要求むま すます多岐にわたり，高度になってきている．技術的に も従来の交配法の壁を越えた新しい育種法が開発されて

表 2．我が国の主要農作物の生産状況 (1986)

\begin{tabular}{|c|c|c|c|c|}
\hline 作 物 & 生産高 & $\begin{array}{c}\text { 作付面積 } \\
\text { (方 ha) }\end{array}$ & $\begin{array}{c}\text { 単位収量 } \\
\text { (t/ha) }\end{array}$ & $\begin{array}{c}\text { 自給率 } \\
(\%)\end{array}$ \\
\hline 米 & 1,165 & 228 & 5.1 & 108 \\
\hline 麦 類 & 122 & 35 & 3.5 & 14 \\
\hline 豆 類 & 25 & 24 & 1.0 & 8 \\
\hline 野 菜 & 1,551 & 64 & 24.4 & 95 \\
\hline
\end{tabular}

（昭和 62 年度版農業白書より）
きており，21 世紀に繫がる技術として大きな期待が掛 けられている. 農業問題の救世主となるかも知れない新 育種法の個々の技術について以下に概説してみたい。

\section{3. 新しい育種技術}

従来の交配を主体とした育種法に対し，種々の培養技 術を基盤にした品種改良の方法を新育種法と呼んで行 く.この中には大きく分けて, 組織・細胞培養, 細胞融 合, 遺伝子操作の技術があり, それぞれは更に細かくい くつかの技術に分けて呼ばれることもある. 表 4 にその 代表的なあのを示したが，これらは目的により，種々の 選抜法と組合せて使用される場合もある。例えば, 除草 剂, 病原菌毒素, アミノ酸アナログなどを培地に添加し, それぞれに耐性の植物を作り出すことも可能である，し かし，これらの新育種法はそれだけで独立に存在するも のではなく，また従来の交配法にとって代わる技術でも ない，これらは育種素材を拡大するための技術であり，

表 4. 新育種法

\begin{tabular}{cl}
\hline \hline \multicolumn{1}{c|}{ 技 術 } & \multicolumn{1}{c}{ 育種への応用 } \\
\hline $\begin{array}{c}\text { 組織・細胞培養 } \\
\text { 茎頂培養 }\end{array}$ & 大量増殖 \\
成長点培養 & ウイルスフリー植物 \\
カルス培養 & 有用変異の選抜 \\
プロトプラスト培養 & 有用変異の選抜 \\
胚・子房培養 & 交雑範囲の拡大 \\
葯・花粉培養 & 固定期間の短縮 \\
\hline 細胞融合 & \\
体細胞雑種 & \\
(ハイブリット) & 核遺伝子の導入 \\
細胞質雑種 & \\
(サイブリッド & 細胞質遺伝子の導入 \\
\hline 遺伝子操作 & \\
\hline
\end{tabular}

表 3、穀物の主要生産国と輸出入状況 (1985)

\begin{tabular}{|c|c|c|c|c|c|}
\hline 国 & 名 & \multirow{2}{*}{$\frac{\text { 生産高（億トン） }}{3.5}$} & \multirow{2}{*}{$\begin{array}{c}\begin{array}{c}\text { 全生産高に対する } \\
\text { 生産割合 }(\%)\end{array} \\
19\end{array}$} & \multirow{2}{*}{$\frac{\text { 輸出量（億トン） }}{0.8}$} & 輸入量（億トン） \\
\hline ア & メリ & & & & \\
\hline 中 & 国 & 3.4 & 18 & & \\
\hline ソ & 連 & 1.8 & 10 & & 0.4 \\
\hline 1 & ン & 1.6 & 9 & & \\
\hline $\mathrm{EC}$ & 諸 & 1.4 & 8 & 0.5 & 0.3 \\
\hline \multirow{2}{*}{\multicolumn{2}{|c|}{$\begin{array}{l}\text { オーストラリア } \\
\text { アルゼンチン }\end{array}$}} & 0.26 & 1.4 & 0.2 & \\
\hline & & 0.29 & 1.6 & 0.2 & \\
\hline 力 & $t$ & 0.49 & 2.7 & 0.2 & \\
\hline 日 & 本 & 0.16 & 0.1 & & 0.25 \\
\hline \multirow[t]{2}{*}{ そ } & の & 5.5 & 30 & 0.3 & 1.05 \\
\hline & 計 & 18.4 & 100 & 2.2 & 2.2 \\
\hline
\end{tabular}

（FAO 生産年鑑より） 
種の壁を越えて有用な遺伝形質の導入を可能にしてくれ るものである，新品種を生み出すには，交配技術と組合 せて使用して始めて意味のある技術となってくる性質の ものである．それでは，それぞれの技術ごとに，方法， 目的及び実例を含めて説明する。

\section{1 組織・細胞培養}

植物の種々の器官や組織の一部あるいは細胞塊や単細 胞（プロトプラストを含む）を培養するすので，この技 術範ちゅうに入るものはバイオ技術の中でも比較的早い 時期から検討されてきたもので, 既に実用段階に達して いるものも少なくない．この中には次のような技術があ り，培養する組織や材料により名称が付いている。

\subsection{1 茥頂・成長点培養}

植物の成長点を含む部分を無菌的に切り出して, 細胞 の增殖に必要な栄養素を含んだ培地上で多数の芽を生育 させる技術である。この方法で作出された植物はメリク ローンと呼ばれ, 同じ遺伝子組成なので品質がよく揃っ ているのが特徵である，優良な個体を短期間で増殖した り，種子にすると遺伝的に分離してしまうような形質を 持った個体を増殖するときに有効な方法である，既にラ ン, ガーベラ，スターチスなどの多数の花や観葉植物な どで実用化されており, 花の品質向上や増殖率の低い植 物の繁殖などに寄与している。

また，成長点にはウイルスが侵入していないので，成 長点培養によりウイルスフリーの植物を作出することも 可能である. 栄養繁殖性の植物はウィルスに污染されて いる場合が多く, 収量低下や品質低下の原因になってい る。カーネション, カスミ草，イチゴ，ブドウなどの花 や野菜から果樹まで多数の作物でウイルスフリー系統が 作出され，技術的にはごく一般的な手法となっており， 県農試や生産組合, 種苗会社など数多くの機関で実施さ れている. 更に, サッマイモ, ニンニク, ヤマイモなど でも成功しており, 品質のよい農作物を生産できるよう になって来ている.

\subsection{2 カルス培養}

植物の葉・根・茎などの組織の一部分を適当な培地の 上に置くと，カルスと呼ばれる細胞塊を生じ増殖生長を 続ける。このカルスを違った組成の再分化培地に移す と，また茎葉を分化し，根もできて健全な植物体となる。 これらの再生植物の中には，いろいろな突然変異が生じ ることが知られており, 有用な変異体は育種素材として 利用できる。このような変異をソマクローナルバリエー ション（体細胞变異）之呼び, 種々の選抜法と組合せる ことにより効率のよい変異体の獲得が可能となり育種に 利用されている。

例えば，疫病耐性のジャガイモ，メチオニン含量の高 いトウモロコシ，除草剤而性のトウモロコシ，黄色果実 のトマト，フザリウム病耐性のトマトなど多数の有用系 統が㕕成されている。これらの作物の他にも，カルス培
養はほとんどすべての作物で成功しており，イネ，ムギ などの主要穀物でも短秙系統や除草剂而性系統などが選 抜されており，新育種法の 1 つの柱となってきている.

\subsection{3 プロトプラスト培養}

植物の若い葉, 胚軸, 培養細胞などをぺクチナーゼや セルラーゼなどの適当な醅素で処理すると細胞壁を持た ない単細胞が調製できる。この単細胞はプロトプラスト と呼ばれ細胞融合には必須のものである。このプロトプ ラストを培養しカルスを経由して植物体を再生させる と, カルス培養の場合と同様にいろいろな変異体が出現 し，育種に利用することができる。プロトプラスト培養 の特長は, 単細胞由来であるため, カルスの中の細胞は すべて同じ性質を示すことである. また 1 枚のシャーレ の中で 100 万個すの細胞を培養することができるので, 細胞レベルで有用変異を選抜するときには非常に効率の よい培養系であると言える。

プロトプラスト培養により生じる変異はプロトクロー ナルバリエーションとも呼ばれ，ソマクローナルバリエ ーションと区別して使われる場合あある。いずれにして あ, カルス培養やプロトプラスト培養によって生じる変 異は，培養中に植物ホルモンなどの影響で生じた突然変 異や組織の中に隠れていた変異細胞が分裂・堌殖して顕 在化してくるなどの原因によるものと考えられている. また，積極的に突然变異を誘発するために，プロトプラ ストにエックス線や紫外線を照射したり，培地に突然変 異誘発剂を添加することも効果がある.

このようにプロトプラスト培養はいろいろな特長を持 っているが，技術的にはまだ比較的歴史が新しく，1968 年に建部らにより夕バコの葉から酵素的に多量のプロト プラストが安定して採れるようになったのが研究の始ま りである. その後数多くの研究が行われ，ナス科の作物 を主体に成功例が続き，最近ではアブラナ科の作物など を含め, 表 5 に示したように他の科の作物でも培養でき る例が增えてきている，プロトプラスト培養での画期的 なブレイクスルーは, 従来困難であるとされていたイネ 科の作物で培養に成功したことである。これは 1985 年 の出来事で, 我が国の数か所の研究機関でイネのプロト

表 5.プロトプラストから植物体が再生された主な 作物

\begin{tabular}{|c|c|c|c|}
\hline ナ & ス & 科 & $\begin{array}{l}\text { タバコ, ペチュニア, トマト, ナス, } \\
\text { ジャガイモ }\end{array}$ \\
\hline セ & リ & 科 & ニンジン，パセリ \\
\hline ア & ラ & -科 & $\begin{array}{l}\text { キャベッ, ナタネ, ハクラン, } \\
\text { ブロッコリー, ケール }\end{array}$ \\
\hline キ & ク & 科 & レタス, ヒマワリ \\
\hline マ & $x$ & 科 & アルファルファ, クローバー \\
\hline 그 & リ & 科 & アスパラガス \\
\hline イ & ネ & 科 & イネ \\
\hline
\end{tabular}


表 6.プロトプラスト培養により育成された「初夢」の特性

\begin{tabular}{|c|c|c|c|c|c|c|}
\hline 品 種 & (出穂昌) & $\begin{array}{l}\text { 稈 長 } \\
(\mathrm{cm})\end{array}$ & $\begin{array}{c}\text { 穂 長 } \\
(\mathrm{cm})\end{array}$ & 穗 $\left./ \mathrm{m}^{2}\right)$ & $\begin{array}{c}\text { 収 量 } \\
(\mathrm{kg} / 10 \mathrm{a})\end{array}$ & 収量指数 \\
\hline 夢 & 8.27 & 85 & 18.2 & 336 & 445 & 99 \\
\hline コシヒカリ & 8.22 & 94 & 19.2 & 296 & 449 & 100 \\
\hline 日 本 晴 & 8.29 & 84 & 19.8 & 311 & 422 & 94 \\
\hline
\end{tabular}

（昭和 62,63 二加年の平均值：於横浜）

プラスト培養に成功し，世界に先がけて主要穀物で培養 を可能にした。

この技術は稲の育種へと繫がり，プロトプラスト由来 の再生稲の後代に, 種々の変異体が出現することが確認 されている.これらの変異の中には農業的に意義の大き い, 短程化, 早生化, 晚生化など, 従来の放射線育種に 比へ，変異の種類や発生頻度が比較にならない位大きく

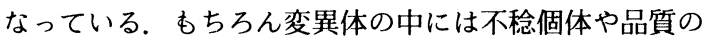
低下など，好ましくない性質も現われるので，通常の育 種の方法と同じに, 収量性, 品質, 食味などの諸形質を 調查する必要がある.

これまでササニシキを原品種とした短稈系統やコシヒ カリを原品種とした短秙晚生系統の選抜が報告されてい る.これらは新品種として登録申請もなされており，培 養に成功して 3 年間で新品種が作出できたことは, 従来 にない画期的な方法であると言える，表 6 にコシヒカリ を培養して作出した新品種 “初夢” の特性を示した。 初 夢は原品種コシヒカリに比べ秙長が約 $10 \mathrm{~cm}$ 短かく, 出穂日が 5 日遅い特長を持っている.この特長は倒状し 難く, 西日本であ栽培が可能な良食味品種として, 栽培 適地の拡大や労働力の分散も可能になるなどの点が期待 されている。

我々はこの方法を“プロトプラスト育種”と名付け, 新育種法の柱の一つとすべく, 既存品種の改良を主体に 検討を続けている。 しかしまだムギ類，トウモロコシ， ダイズなよ゙多くの主要穀類では，再現性のあるプロトプ ラスト培養法が確立されておらず，これが細胞育種の大 きな障壁となっている，現在世界各国の研究機関で培養 系の確立に向けて地道な努力が続けられているので, 少 しづつ成功例が増えて行くことが期待される.

\subsection{4 肧・子房培養}

交配により正常な種子を結実する組合せは, 通常同一 種内の植物間に限定される. しかし比較的近縁な異種植 物の間では受精は成立するが，受精胚の発育が途中で止 まり，完全な種子にまでは達しない組合せのあることが 知られている，このような場合は，受精胚の発育が止ま る前に植物体から取り出して, 適当な培地上で培養して やると，胚はそのまま発達して雑種植物を得ることがで きる.この技術は培地に置く組織の部位により肧培養, 肧珠培養, 子房培養と呼ばれることがあるが, 同じ範ち
ゅうに入る技術である．また，花粉管が花柱内で伸長す ることができないために受精が阻害されているような組 合せの場合には，それぞれの植物から無菌的に肧珠と花 粉を取り出して, 試験管内で受精させそのまま培養して 雑種植物を得ることが可能な例も知られている。

このような肧培養関連の技術を利用して作出された作 物の中には既に市販されているものもある。，ハクランは 30 年位前に, 八クサイとカンラン (キャベッ) の組合せ で胚培養を行って作出された雑種である. その後品種化 の努力が営々として続けられた結果 5 年程前より本格 的な新野菜として登場してきたものである。一方，千宝 菜はコマッナとキャベッの雑種で, $3 \sim 4$ 年で品種化で きた例として有名である。この他にもアブラナ科作物の 中では種々の種間雑種や属間雑種が作出され, 新野菜の 作出や有用遺伝子の導入などが進められている.

\subsection{5 葯 $(や く) ・$ 花粉培養}

植物の場合には雄性生殖細胞である花粉（通常は未成 熟の花粉を使う場合が多い）から適当な培養条件により 植物体を再生させることが可能である．花粉は減数分裂 を経て形成されているので, 花粉由来の植物は通常の植 物の半分の染色体しか持っていない，そのため半数体植 物と呼ばれ，劣性遺伝子も表現型として現われるため劣 性形質の選抜にあ好適である。.またコルヒチンなどの薬 剂を使えば, 通常の染色体数（二倍体）に戻すことがで き，種子も採れるようになる．この倍化した二倍体植物 は同一遺伝子組成を持っているので後代で分離すること がなく，常に同じ形質を持つ子孫を維持することができ る.これは純系植物とも呼ばれ，遺伝形質の固定した植 物となっている．従来の育種法では遺伝形質の固定のた めに 7 8 回の交配が必要で長期間を要していたが，花 粉由来の植物を利用すれば 1 回で固定できるので，大幅 な時間短縮が可能となった，品種を作るためには固定は 必須の過程であり， $\mathrm{F}_{1}$ 種子（一代雑種）を採種する場合 にも両親の形質は固定している必要がある.このように 花粉由来の植物は育種にとって大幅なメリットであり, 半数体育種法と呼ばれ数多くの育種の現場で採用されて いる。この技術も培養する雄性器官によって, 葯培養 （花粉の詰った袋を葯という）と花粉培養に分けられる. 菞培養は比較的早い時期（1964 年）に確立された技術 で，現在では 100 種を越える植物で成功している．花粉 
培養の方は技術的にはまだ難しく, 夕バコやナタネなど の一部の植物でしか成功していない，従って育種には葯 培養がよく使われており, 我が国であイネの育種に実用 的に組込まれている. 特に中国では盛んに利用されてい て, イネ, トウモロコシ, ナスなどの品種が育成されて いる.

\section{2 細胞融合}

種の異なる植物から, 有用な遺伝子を導入したいとき に, 肧培養などの方法によっても雑種植物が得られない 場合には細胞融合が有力な手段となる，細胞融合を行う ためには 2 種類の植物からプロトプラストを調製し, 必 要な前処理を施した後に両者をほぼ同じ割合で混合し融 合処理を行う. 融合処理は二つの方法があり, 一つはポ リエチレングリコール (PEG) やデキストランのような 水溶性高分子物質で処理する方法, もう一つは電気的な 処理によるものがある. 薬昘で処理すると細胞同志が凝 集し, 同時に細胞膜の性質が一次的に変化することによ って融合が起こる. 電気融合では電極間に混合した 2 種 の細胞を置き, 高周波の電気を流すと細胞同志が付着し て電極に対し直角に亚んでくるので, その後で直流のパ ルスを数回与えると細胞が融合する．いずれの方法でも 余り強い処理を加えると細胞に損傷を与えるので, 融合 率が 1〜10\%程度になるように処理を行う。また, 融合 は細胞間でランダムに起こるため, 処理後には目的とす る雑種細胞の他に，2種の同種融合細胞と融合していな い多数の両親の細胞が存在している.これらの細胞の中 から目的とする細胞だけを残すために選抜を行う必要が ある，選抜は薬剤処理, 培養条件, 放射線照射, ピック アップなよ゙両親の特性に応じ適当に組合せて行うことが
できる．培養を経て再生してきた植物が雑種であるか否 かの確認は, その形態的な特徴, 染色体の解析, アイソ ザィムの検定, DNA レベルの検定なよ゙を行って調べる.

前述の如く, プロトプラストは葉, 肧軸, 培養細胞な よ゙を酵素的に処理して調製するので，いつでも実験が可 能である. また, 生殖細胞を使わない無性的な雑種作出 の方法なので, 広い範囲の素材が使え, 遺伝子導入の範 囲が広がることが大きな特長である，融合の場合も目的 により二つに分けて考えることができる，一つは核にコ 一ドされている遺伝子に着目した場合で, 通常の融合に より作出される体細胞雑種（ハイブリッド）を作出する 方法である. あう一つは, 核以外の細胞小器官にコード されている遺伝子に着目する場合で, 一方の核を除去あ るいは不活化した後に融合して, 片親の核と両親の細胞 質を持った細胞質雑種（サイブリッド）を作出する方法 である.

\subsection{1 体細胞雑種}

体細胞雑種作出の歴史は比較的新しく, 1972 年に夕 バコの野生種間で成功したのが最初である. それから 20 年足らずの間に, タバコやペチュニアなどのナス科 植物の中で, 種間雑種の作出が相ついで報告され, 1978 年には有名なポマト（ジャガイモとトマトの雑種）の作 出が報告されている. 最近ではアブラナ科やイネ科, 更 にはミカン科やウリ科の植物でも種間雑種や属間雑種が 作出されており, 細胞融合の技術は特に我が国で大幅に 進展してきている.（表 7).

しかし, 細胞融合でどのような組合せでも雑種植物が 作れるかと言うと, まだそこまでは無理で, 現在のとこ ろ同一科内の種間, 属間, 族間での雑種植物の作出例は

表 7. 細胞融合により作出された体細胞雑種の例

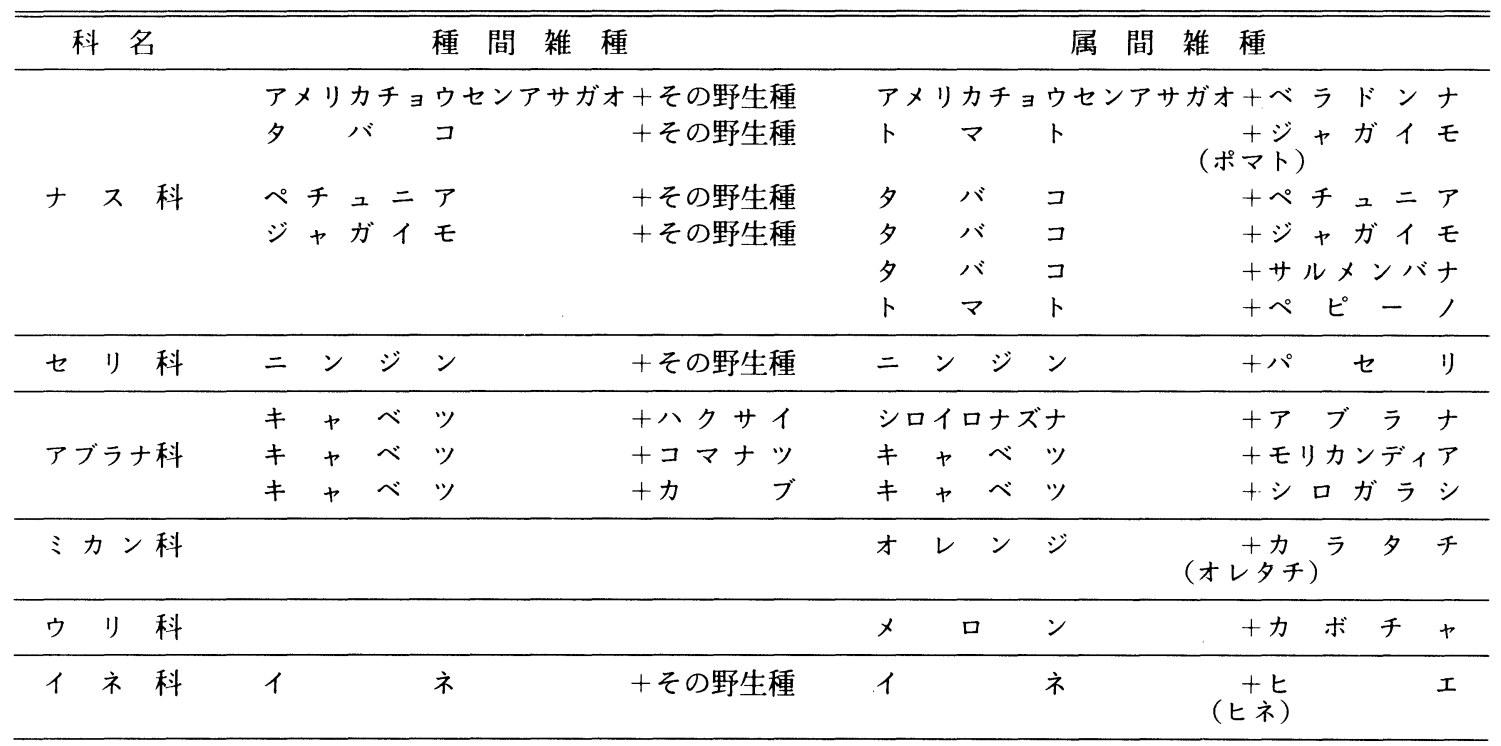


あるが，科が異なった植物間での成功例はない，このよ うな遠縁間の組合せでも細胞同志を融合させることは可 能で, しかもカルスまで成長できる場合ああり, イネと ダイズの雑種カルスの作出が報告されているが, 植物体 は得られていない. 更に言えば, たとえ雑種植物が得ら れても稔性がなければ育種素材として使うことができな い. 前出のポマトも稔性がないために有効に利用される までには至っていない.

この様に体細胞雑種を育種に利用して行くためには, 各ステップごとにバリアーが存在している. しかし, 最 近ではこのような障壁を取り除くための試みも行われて おり, 片方の細胞の染色体の一部だけを導入する融合法 が検討されている.この方法は通常の全部の染色体を導 入する対称融合に対し, 非対称融合（または部分融合） と呼ばれている. 片方の組胞の染色体の一部を取り除く ために，エックス線やガンマー線などの放射線で細胞を 照射した後に融合する方法がとられている．この方法で パセリの染色体を一本だけニンジンに導入した例やハク サイやカブの染色体の一部をキャベッに導入した例など が報告されている. 将来的には, 染色体を健全なままで 細胞から取り出して, 目的とする染色体だけを細胞に導 入するような染色体工学的手法が開発されて行くあの之 期待されている.

\subsection{2 細胞質雑種}

植物細胞には葉緑体とミトコンドリアに光合成や呼吸 に関連した遺伝情報が存在することが知られている，通 常の交配では, このような細胞質遺伝子は母性遺伝する ため，その性質を変えることができない．また特定の系 統に細胞質遺伝子を導入するためには，戻し交配を 7〜 8 回繰返して核置換をする必要があり長期間を要する.

このように細胞質遺伝形質の育種にはいくつかの制約が あったが, 融合により細胞質雑種を作出することができ るようになり解決の見通しが出てきている.

細胞質遺伝子に着目した場合, 核遺伝子は不必要にな るため, 除去したり不活化したりする必要がある. 核を 除去するためには，核と細胞質との比重差を利用して， 40,000 回転位の超遠心分離により脱核した後の細胞 （サイトプラストと呼ぶ）を融合に用いる. また核遺伝子 の不活化には放射線の照射が有効である. 照射線量は植 物の種類によって差はあるが 40〜80 KR 位が必要であ る、培養により得られた細胞質雑種は片親の染色体と両 親の細胞質を持っているが，これまでの実験結果ではミ トコンドリアは両者の間で組換えが起こり, 葉緑体はど ちらか一方の親由来だけになることが知られている.

この方法を用いて別々の個体で見つかった除草剂耐性 （葉緑体にコード）と雄性不稔性（ミトコンドリアにコー ド）とを同一個体に集積できた例が報告されている，特 に雄性不稔性はF $\mathrm{F}_{1}$ 種子の採種に有効なため重要な農業 形質で, 融合により短時間で目的の系統を不稔化できる
ようになってきたために, 数多くの報告が目立つように なった. タバコやナタネでの報告につづいて, 我が国で の研究成果が増加しており，ニンジンやイネでも雄性不 稔が導入できた結果が報告されている. 細胞質雑種は通 常此性稔性は高いので育種への応用の期待が大きく, 実 用品種の育成も間近い屯のと思われる.

\section{3 遺伝子操作}

細胞融合では種の壁を越えて遺伝子を導入することが 可能であるが, 雑種植物を得るには組合せ可能な範囲に 自ずと限界があること, また雑種植物が作出できても稔 性がなかったり，目的遺伝子だけを残すために多大の労 力と時間を要するなどの問題点も残されている. 有用遺 伝子だけを植物に導入することができれば, 育種法とし ては理想的な方法となる. そこで微生物に端を発した組 換え DNA の技術が植物の分野にも導入され，欧米をは じめ我が国でも活発に研究が進められている.

遺伝子は 4 種類のデオキシリボ核酸 (DNA) の配列の 仕方によって決定されており, これは細菌から高等動植 物まで基本的には同じ仕組みである. ウイルスの中には リボ核酸 (RNA) によって遺伝情報を伝えているものも ある. 形態, 花色, 味, 収量, 病虫害抵抗性など作物の すべての特性は遺伝子によって決定されており，品種改 良はDNA の配列を改変して行くことに他ならない.

組換えDNA の技術は種々の生物から切り出した有用 遺伝子を含む DNA 断片や mRNA から作製した cDNA などをべクターに組込んで, 植物細胞に導入し培養と選 抜により目的遺伝子が発現している植物体を得ること で，遺伝的にその性質を変えることを可能にしている. 植物に遺伝子を導入する一般的な方法はアグロバクテリ ウムと呼ばれる土壌細菌の持っている $\mathrm{Ti}$ プラスミドを 利用して行われる.この菌は自然界で Ti プラスミドの 中の T-DNA と呼ばれる部分を植物の染色体に組込み, クラウンゴールと言われる腫瘍を形成すると共に, 本菌 だけが利用できるオパインと総称される特殊なアミノ酸 を植物に生産させて増殖している.この実に巧妙な自然 界のからくりに着目し， T-DNA の中に有用遺伝子を人

表 8. 外来遺伝子が導入された主な作物

\begin{tabular}{|c|c|c|}
\hline ナ & ス 科 & $\begin{array}{l}\text { タバコ, ペチュニア, トマト, } \\
\text { ジャガイモ }\end{array}$ \\
\hline$セ$ & リ科 & ニンジン, セロリ \\
\hline २ & × 科 & $\begin{array}{l}\text { アルファルファ, エンドウ, } \\
\text { 白クローバー, ダイズ }\end{array}$ \\
\hline ウ & リ 科 & キュウリ \\
\hline キ & ク 科 & レタス, ヒマワリ \\
\hline アン & ラナ科 & ナタネ, キャベッ, 白イヌナズナ \\
\hline イ & ネ 科 & イネ, トウモロコシ \\
\hline そ & の 他 & $\begin{array}{l}\text { アスパラガス, テンサイ, ワタ, } \\
\text { ポプラ, クルミ }\end{array}$ \\
\hline
\end{tabular}


為的に組込んでおけば，植物にその遺伝子が導入されて 植物の性質を変えることができると考えて実験が繰り返 された。最初に用いられた遺伝子は大腸菌由来のカナマ イシン耐性遺伝子である。そして 1983 年に始めてカナ マイシン耐性遺伝子をぺチュニアに導入し発現させて耐 性の植物を作出することに成功した。

その後短期間の中に植物での遺伝子操作の技術は大幅 に進展し，今ではナス科植物を始めとして 20 種以上の 植物で外来遺伝子の導入に成功したことが報告されてい る (表 8).アグロバクテリウムが感染しないイネ科など の植物では，プロトプラストを用い電気処理（エレクト ロポレーション）などによって直接ベクタープラスミド を細胞に導入し，形質転換植物を作出することに成功し ている．特にイネではプロトプラスト培養の効率が高い ことから, 再現性よく高頻度に外来遺伝子の発現ができ るようになっており，ハイグロマイシン耐性遺伝子や $\beta$ グルキュロニダーゼ (GUS) の遺伝子が導入され後代へ の伝達むされていることが報告されている.

遺伝子操作屯実用段階を迎えており，農業的に重要な 形質を決めているいくつかの遺伝子が導入され，アメリ 力を中心として野外試験が実施されている．現在のとこ ろその主な遺伝子は，種々の除草剤に対する而性遺伝 子, BT (バチルスチューリンゲンシスの殺虫性タンパク 質）やCPTI（ササゲのトリプシンインヒビター）などの 耐虫性遺伝子，各種ウイルスの外被タンパク質遺伝子 （ウイルス耐性）などで，夕バコ，トマト，ジャガイモな どに導入されて安全性評価のための詳細な試験が行われ ている，その他，種々のストレスにより誘導されるタン パク質, 植物の生育段階に応じ器官特異的に発現する夕 ンパク質, 光などにより誘導されるタンパク質などの制 御の機構之遺伝子発現の関係などが解明されてきてお り, 徐々に分子レベルでの植物の機能解析が進んできて いる. 今後は品質（色，味，成分など）や収量などに関
係する二次代謝産物の生合成遺伝子, 光合成関連遺伝 子, エネルギー代謝関連遺伝子，チッ素代謝関連遗伝子 などの解明が待たれるところであるが，これらの生体の 主要な機能には複数の遺伝子が関与しており技術的にも 困難な点が多く, 植物生理や生化学分野の研究と歩調を 合わせて行くことが重要と思われる。

遺伝子操作法では植物由来の遺伝子だけでなく，ウィ ルス，バクテリア，動物などあらゆる生物の遺伝子が利 用でき，遺伝子源が格段に広がることが期待できる。 ま た目的遺伝子だけが導入できるため，以後の育種作業は 比較的楽で，今後ますます育種技術としての位置付けが 重要になってくるものと思われる.

4.おわりに

世界と我が国の食糧及び農業事情について概要を述 べ，バイオテクノロジーを用いた新しい育種技術につい て現状と可能性について説明してきた。細胞融合や遺伝 子操作などの技術が育種法として定着するまでには, ま だまだ解明されなければならない課題も数多く残されて いるが，画期的な手法でああり，今後の食糧問題を克服 するための有力な手段として熱い期待がかけられてい る. しかし過大に期待することなく, 過度に拒絶するこ となく，技術内容を正しく理解し，判断する力を養って 行くことが，身近な食糧に関する技術であるだけに特に 重要であると思う。

\section{参考文献}

1)（財)矢野恒太記念会編：“世界国勢図会” 1988 1989 年 版, 国勢社

2) 農林水産省編：農業白書 昭和 62 年度, 農林統計協会.

3) Vasil, I.K. ed.: "Cell Culture and Somatic Cell Genetics of Plants". (1984), Academic Press.

4 ) Shepard, J.F., et al.: Science 208, 17 24 (1980).

5) Evans, D.A.: Trend in Genetics 5, 46 50 (1989).

6) Ratner, M;: Biothechnology 7, 337 341 (1989). 